\title{
Redasoft Plasmid 1.1: Software for Easy, Efficient Cloning and Map Drawing
}

\author{
Danny Reda* and Alexandra Carmichael Reda \\ Redasoft, Toronto, Ontario, Canada
}

\begin{abstract}
A computer program is described which creates circular and linear genetic maps with or without sequences, performs restriction analysis, and simulates basic molecular cloning operations. Redasoft Plasmid 1.1 is a user-friendly program for Windows 95/98/NT/2000, designed to generate high quality genetic maps for presentation and publication and to aid the molecular biologist in selecting restriction endonucleases for common molecular cloning experiments. The program incorporates an integrated web browser and can automatically generate complete, labeled maps from sequences on the Internet.
\end{abstract}

\section{Introduction}

Molecular biology is being revolutionized by an explosion of information that is challenging researchers to work with increasing efficiency in order to compete effectively. Computers have frequently come to the rescue, but many scientists still choose to do some things the old way, such as staring at printouts of sequences to try to figure out a cloning strategy. Software is available that facillitates many tasks. Redasoft Plasmid 1.1 is designed to reduce the time needed to prepare cloning strategies and generate high quality genetic maps for presentation and publication. Plasmid's integrated web browser permits the creation of maps from sequences on the Internet with a single mouse click. Maps can be created with or without sequences and can be extensively customized. Powerful restriction analysis and virtual cloning features speed up the process of designing cloning experiments. Plasmid's ease of use and high quality maps make it an ideal tool for the molecular biologist.

\section{Features and Benefits}

\section{Creating Maps}

Redasoft Plasmid 1.1 permits the creation of maps with or without sequence information. New maps without sequences can be created simply by entering a name, size and type of map (circular or linear). Plasmid can also automatically produce a map directly from a sequence. Sequences used to generate maps can originate from several sources, including a computer hard disk, a web page on the Internet (such as NCBI, the National Center

*For correspondence. Email: info@redasoft.com for Biotechnology Information), or the Windows Clipboard. Plasmid can import sequences in GenBank, EMBL, GCG, FASTA and ASCII formats. In addition, its ASCII importing is flexible enough to be able to import sequences in virtually any other format.

\section{Web Integration}

One of Plasmid's most useful and innovative features is its integrated web browser. Researchers frequently need to access sequences on the Internet and it is convenient to be able to import these sequences into Plasmid. While a separate web browser would require the saving of a sequence to the computer hard disk before importing it into another application, Plasmid lets you import the sequence directly into the program with a single mouse click (Figure 1). As with other web browsers, a favorites list is available and includes links to the National Center for Biotechnology Information (NCBI), VectorDB, and the Sequence Retrieval System (SRS, EMBL-EBI).

\section{Restriction Analysis}

Another powerful tool is Plasmid's restriction analysis feature, which can find and display restriction sites on maps. The program comes with a large database of nearly 1000 restriction enzymes (provided by REBASE, Dr. Richard J. Roberts, 2000), which can be updated regularly from Redasoft's web site. Restriction analysis can be performed using all enzymes, the commercially available subset, or one of multiple custom subsets. For example, a custom subset can be designed based on all the enzymes available in an individual lab. Enzymes can be selected individually or filtered by any combination of cut frequency, size of recognition site or type of overhang (Figure 2). When selecting individual enzymes, the recognition sequence of each is shown and the exact cut site is indicated with $a^{\wedge}$ symbol. After restriction analysis is performed, isoschizomers can be removed from the map so that only one representative enzyme from each group is shown.

\section{Virtual Cloning}

An innovative addition to Plasmid 1.1 is the simulation of cloning experiments by the insertion and deletion of fragments. This feature can be useful whether or not the fragment has a sequence. For example, deletion of fragments with or without sequences can be used to generate precise, to-scale maps of successive deletion constructs, and insertion of fragments with sequences can be paired with restriction analysis to prepare diagnostic digests that verify correct insertion. Inserting and deleting fragments will change the size of the map, with the option of preserving either the map size or scale on the page. Plasmid will automatically adjust the relative sizes and positions of map features, such as regions and markers, according to the size and position of the fragment being inserted or deleted. This feature also makes it very easy to create new maps derived from existing ones. 


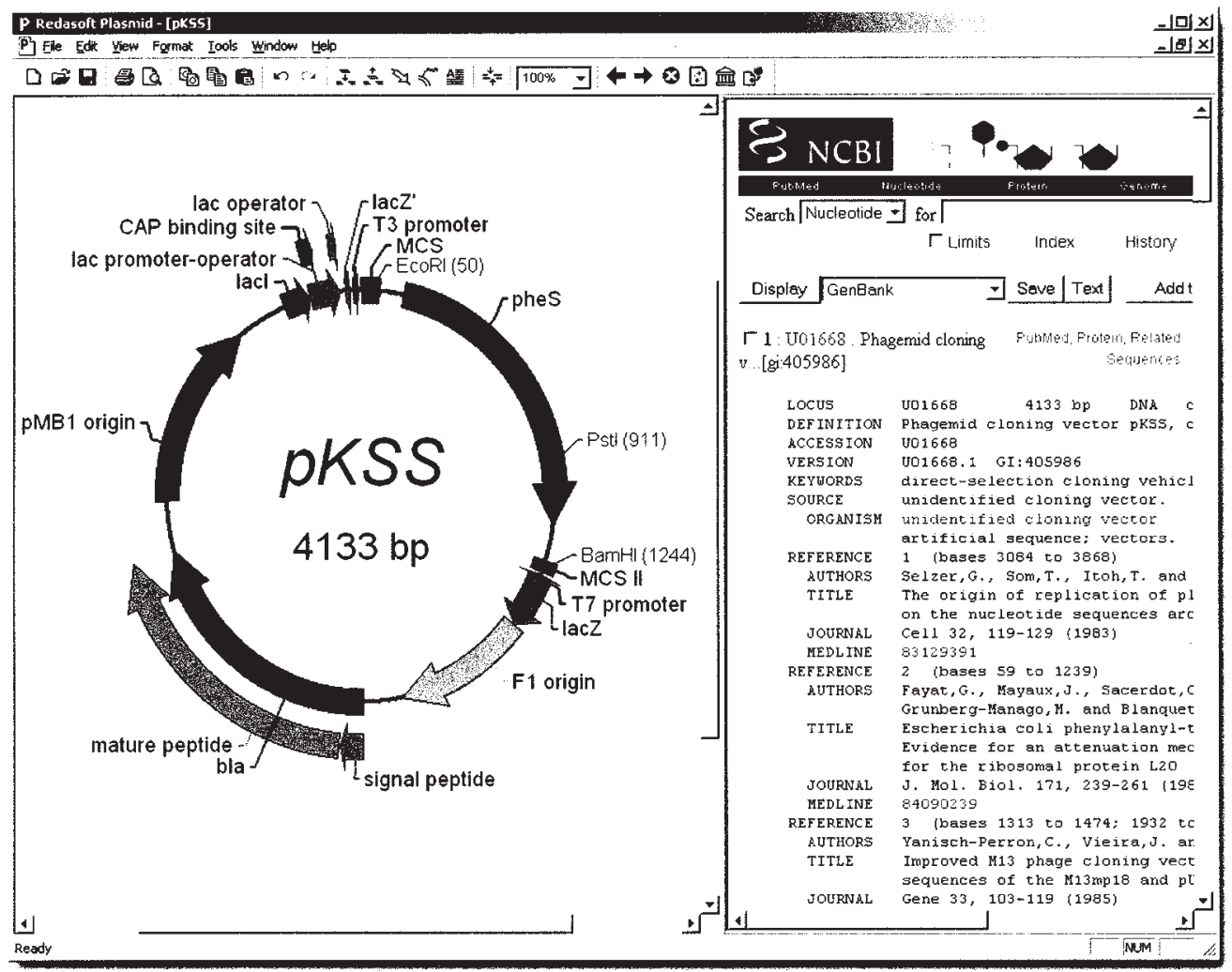

Figure 1. Redasoft Plasmid 1.1 includes an integrated web browser that gives you instant access to virtually every publicly available sequence. The figure shows the result of a nucleotide query at NCBI. With a single mouse click, you can generate a fully labeled color map.

\section{Timesaving Features}

Plasmid has several other timesaving features. For example, when new maps are generated from sequence files containing feature tables (e.g. GenBank files), the listed map features are automatically added to the map, colored, and labeled. This means less work is needed to create complete maps. Although region colors can be individually specified, an AutoColor Regions command in the Format menu will randomly apply colors to all regions, creating pleasing results in seconds, instead of minutes. This is especially useful when maps have many regions. The manual addition of features to a map is straightforward and many regions or markers can be added consecutively, so it is not necessary to go back to the menu command or toolbar button each time. In addition, the program automatically positions text labels around a map so that they don't overlap, while still allowing them to be individually positioned anywhere on the page. Plasmid's user interface is intuitive and is accompanied by extensive help files and online support.

\section{Customization}

Map features, such as region widths, lines, colors and fonts are customizable and default settings can be specified. For example, the default font used to label regions can be changed so that all new regions will use that font. The size and position of the map on the page can be changed visually by dragging with the mouse. The map size can also be specified to a precise scale, in bp per inch. Textboxes can be added anywhere on the page and can be customized.

\section{Sharing with other Programs and Printing}

The Windows Clipboard is a valuable tool for sharing sequence information and maps between Plasmid and other Windows programs. The sequence of the entire map or that of any region can be copied and pasted into other programs, such as a web browser, for further analysis. In addition, sequences can easily be copied from other programs and pasted into Plasmid to generate new maps or new fragments in existing maps. Maps may be copied to the Clipboard as high-resolution graphics for pasting into programs such as Microsoft Word or PowerPoint for publication or presentation. Pasted maps can be scaled without loss of quality, since they are vector-based. Maps can also be saved in BMP format, which can be converted to GIF or JPG format in virtually any graphics program for easy publishing to the web. Printing is facilitated by Plasmid's WYSIWYG (What You See Is What You Get) interface, which ensures that printed maps look as they do on screen. The resolution of the printout is limited only by your printer. 


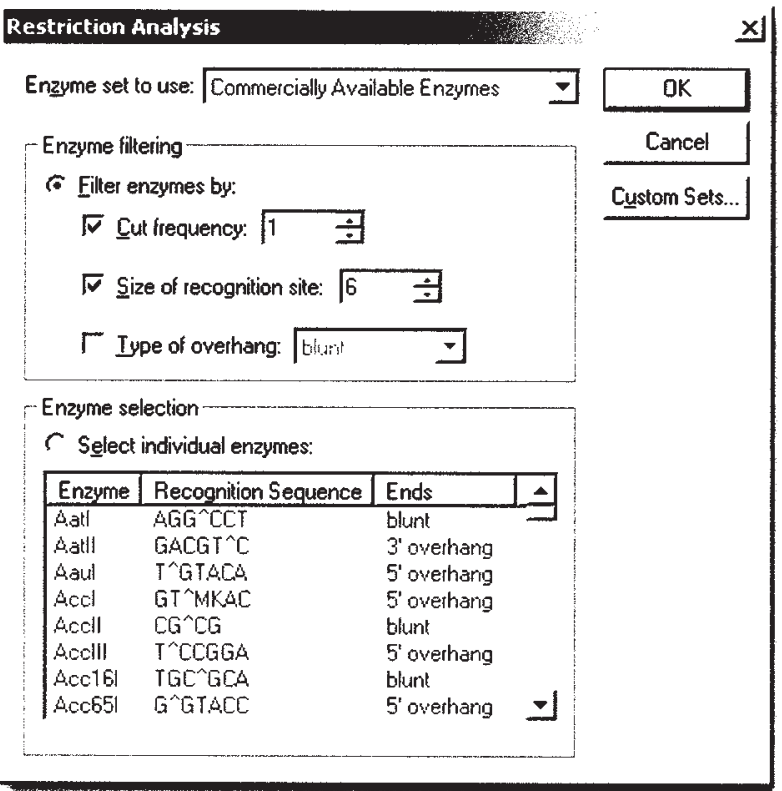

Figure 2. Plasmid's Restriction Analysis dialog lets you select enzymes individually or filter them by any combination of cut frequency, size of recognition site and type of overhang.

\section{Discussion}

Biological research is in the midst of an explosion of information. Researchers today are faced with an exponential increase in publications and genetic information, and the overload of data necessitates the use of computer software in order to become more efficient and productive. Scientists must reengineer every lab process in order to remain at the very forefront of their fields. Because molecular cloning is one of the most common activities in labs today, any tool that can make any part of the process consistently more efficient will result in significant long-term timesavings and measurable productivity gains. Redasoft Plasmid 1.1 is a versatile, userfriendly tool that was specifically designed to help researchers save time designing cloning experiments and publishing high quality genetic maps. In addition to all of its useful features, Plasmid costs less than any other commercially available software of its kind. The program runs in Windows 95/98/NT/2000, however no Macintosh version is currently available. Plasmid's innovative web integration, powerful restriction analysis and virtual cloning make it a valuable addition to any molecular research lab.

Plasmid 1.1 is available from Redasoft, Toronto, Ontario, Canada for $\$ 199.95$. A free trial version is available to download at www.redasoft.com 


\section{Further Reading}

Caister Academic Press is a leading academic publisher of advanced texts in microbiology, molecular biology and medical research. Full details of all our publications at caister.com

- MALDI-TOF Mass Spectrometry in Microbiology Edited by: M Kostrzewa, S Schubert (2016) www.caister.com/malditof

- Aspergillus and Penicillium in the Post-genomic Era Edited by: RP Vries, IB Gelber, MR Andersen (2016) www.caister.com/aspergillus2

- The Bacteriocins: Current Knowledge and Future Prospects Edited by: RL Dorit, SM Roy, MA Riley (2016)

www.caister.com/bacteriocins

- Omics in Plant Disease Resistance Edited by: V Bhadauria (2016) www.caister.com/opd

- Acidophiles: Life in Extremely Acidic Environments Edited by: R Quatrini, DB Johnson (2016) www.caister.com/acidophiles

- Climate Change and Microbial Ecology: Current Research and Future Trend

Edited by: J Marxsen (2016)

www.caister.com/climate

- Biofilms in Bioremediation: Current Research and Emerging Technologies

Edited by: G Lear (2016)

www.caister.com/biorem

- Microalgae: Current Research and Applications Edited by: MN Tsaloglou (2016) www.caister.com/microalgae

- Gas Plasma Sterilization in Microbiology: Theory, Applications, Pitfalls and New Perspectives Edited by: H Shintani, A Sakudo (2016) www.caister.com/gasplasma

- Virus Evolution: Current Research and Future Directions Edited by: SC Weaver, M Denison, M Roossinck, et al. (2016) www.caister.com/virusevol

- Arboviruses: Molecular Biology, Evolution and Control Edited by: N Vasilakis, DJ Gubler (2016) www.caister.com/arbo

- Shigella: Molecular and Cellular Biology Edited by: WD Picking, WL Picking (2016) www.caister.com/shigella

-Aquatic Biofilms: Ecology, Water Quality and Wastewater Treatment

Edited by: AM Romaní, H Guasch, MD Balaguer (2016)

www.caister.com/aquaticbiofilms

- Alphaviruses: Current Biology

Edited by: S Mahalingam, L Herrero, B Herring (2016)

www.caister.com/alpha

- Thermophilic Microorganisms

Edited by: F Li (2015)

www.caister.com/thermophile
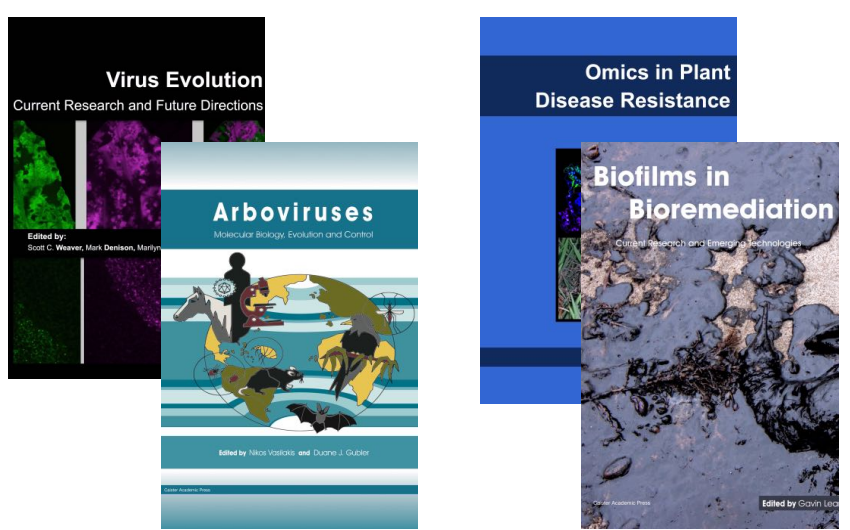
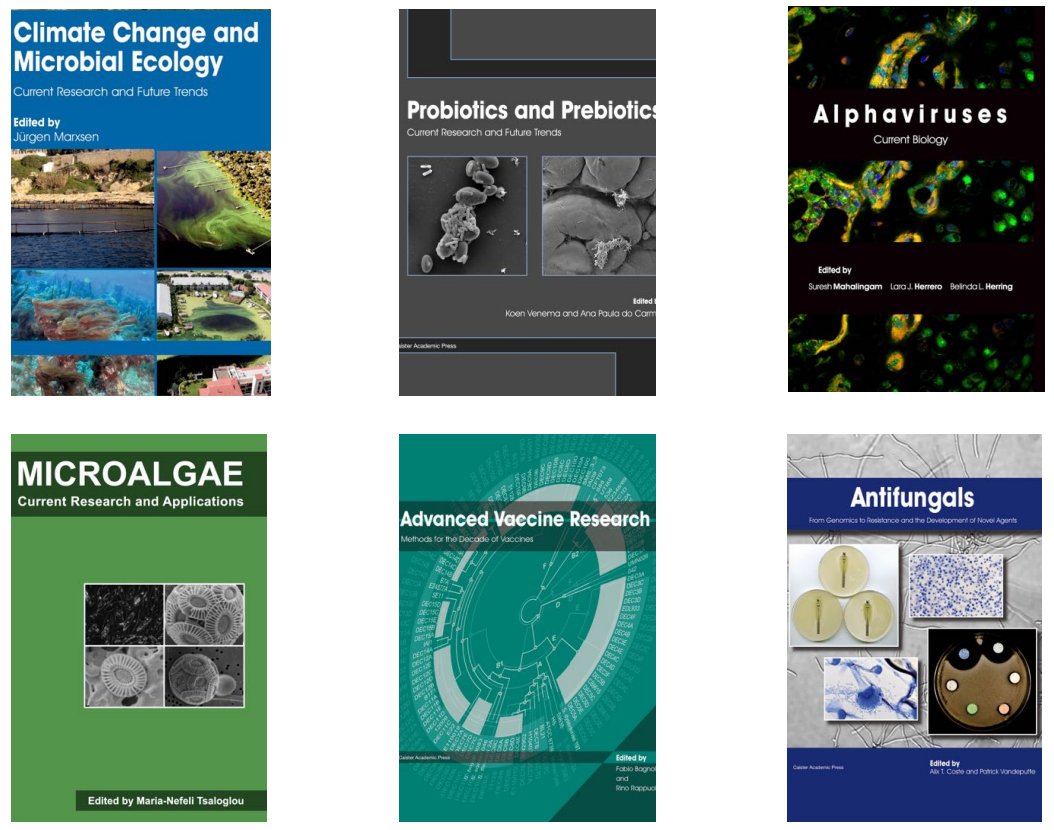

- Flow Cytometry in Microbiology: Technology and Applications Edited by: MG Wilkinson (2015) www.caister.com/flow

- Probiotics and Prebiotics: Current Research and Future Trends Edited by: K Venema, AP Carmo (2015) www.caister.com/probiotics

- Epigenetics: Current Research and Emerging Trends Edited by: BP Chadwick (2015) www.caister.com/epigenetics2015

- Corynebacterium glutamicum: From Systems Biology to Biotechnological Applications

Edited by: A Burkovski (2015)

www.caister.com/cory2

- Advanced Vaccine Research Methods for the Decade of Vaccines

Edited by: F Bagnoli, R Rappuoli (2015)

www.caister.com/vaccines

- Antifungals: From Genomics to Resistance and the Development of Novel Agents

Edited by: AT Coste, P Vandeputte (2015)

www.caister.com/antifungals

- Bacteria-Plant Interactions: Advanced Research and Future Trends Edited by: J Murillo, BA Vinatzer, RW Jackson, et al. (2015) www.caister.com/bacteria-plant

\section{- Aeromonas}

Edited by: J Graf (2015)

www.caister.com/aeromonas

- Antibiotics: Current Innovations and Future Trends

Edited by: S Sánchez, AL Demain (2015)

www.caister.com/antibiotics

- Leishmania: Current Biology and Contro Edited by: S Adak, R Datta (2015) www.caister.com/leish2

- Acanthamoeba: Biology and Pathogenesis (2nd edition) Author: NA Khan (2015)

www.caister.com/acanthamoeba2

- Microarrays: Current Technology, Innovations and Applications Edited by: Z He (2014)

www.caister.com/microarrays2

- Metagenomics of the Microbial Nitrogen Cycle: Theory, Methods and Applications

Edited by: D Marco (2014)

www.caister.com/n2 